\title{
Bartonella Infections in Cats and Cat Fleas in Lithuania
}

\author{
Miglè Razgūnaitė ${ }^{1}$, Indrè Lipatova ${ }^{1}$, Algimantas Paulauskas ${ }^{1}$, , Birutè Karvelienè ${ }^{2}$, Vita Riškevičienè ${ }^{2}$ \\ and Jana Radzijevskaja ${ }^{1}$
}

1 Faculty of Natural Sciences, Vytautas Magnus University, K. Donelaičio Str. 58, LT-44248 Kaunas, Lithuania; migle.razgunaite@vdu.lt (M.R.); indre.lipatova@vdu.lt (I.L.); jana.radzijevskaja@vdu.lt (J.R.)

2 Faculty of Veterinary Medicine, Lithuanian University of Health Sciences, Tilžès Str. 18, LT-47181 Kaunas, Lithuania; birute.karveliene@lsmuni.lt (B.K.); vita.riskeviciene@lsmuni.lt (V.R.)

* Correspondence: algimantas.paulauskas@vdu.lt

Citation: Razgūnaitè, M.; Lipatova,

I.; Paulauskas, A.; Karvelienė, B.;

Riškevičienè, V.; Radzijevskaja, J.

Bartonella Infections in Cats and Cat

Fleas in Lithuania. Pathogens 2021, 10,

1209. https://doi.org/10.3390/

pathogens10091209

Academic Editor: Edward B.

Breitschwerdt

Received: 24 August 2021

Accepted: 14 September 2021

Published: 17 September 2021

Publisher's Note: MDPI stays neutral with regard to jurisdictional claims in published maps and institutional affiliations.

Copyright: (C) 2021 by the authors. Licensee MDPI, Basel, Switzerland. This article is an open access article distributed under the terms and conditions of the Creative Commons Attribution (CC BY) license (https:/ / creativecommons.org/licenses/by/ $4.0 /)$.

\begin{abstract}
Bartonella are vector-borne parasitic bacteria that cause zoonotic infections in humans. One of the most common infections is cat-scratch disease caused by Bartonella henselae and Bartonella clarridgeiae. Cats are the major reservoir for these two species of bacteria, while cat fleas are vectors for the transmission of infection agents among cats. The aim of the present study was to investigate the presence of Bartonella infections in stray and pet cats and in cat fleas in Lithuania. Blood samples were taken from 163 cats presented in pet clinics and animal shelters. A total of 102 fleas representing two species, Ctenocephalides felis and Ctenocephalides canis, were collected from 12 owned cats that live both outdoors and indoors. Bartonella DNA in samples was detected using a nested PCR targeting the 16S-23S rRNA intergenic spacer (ITS) region. Bartonella DNA was detected in $4.9 \%(8 / 163)$ of the cats and $29.4 \%(30 / 102)$ of the fleas. Sequence analysis of the ITS region showed that the cats and fleas were infected with B. henselae, B. clarridgeiae and Bartonella sp., closely related to B. schoenbuchensis. This study is the first report on the prevalence and molecular characterization of Bartonella spp. in cats and cat fleas in Lithuania.
\end{abstract}

Keywords: pet cats; stray cats; cat fleas; Bartonella henselae; Bartonella clarridgeiae; 16S-23S rRNA ITS

\section{Introduction}

Domestic pets are susceptible to infection by various species of Bartonella and can play a role in human infection. Cats (Felis catus) are considered the main reservoir of three zoonotic Bartonella species: B. henselae, B. clarridgeiae (both of which can cause catscratch disease) and B. koehlerae (a causative agent of endocarditis in humans). Cat-scratch disease (CSD) is the best-known infection caused by Bartonella bacteria [1-4]. This zoonosis has a worldwide distribution, but is more commonly detected in warmer climate zones. In northern temperate zones, it occurs more frequently between August and October, usually in humid, warm locales [5-7]. Cats can also be the accidental host of B. quintana, B. vinsonii subsp. berkhoffii, B. elizabethae, B. bovis (ex weissii), B. volans-like, B. grahamii, $B$. rochalimae and $B$. washoensis $[1,3,8-10]$. The cat flea, Ctenocephalides felis, is the main vector of $B$. henselae and a potential vector of B. clarridgeiae and B. koehlerae [11-13]. Bartonella quintana, B. rochalimae, B. elizabethae, B. grahamii, and B. alsatica have been also detected in cat fleas [13-18]. Bartonella vinsonii subsp. berkhoffii has been amplified from Pullex spp. fleas [3].

Cats are in close contact with humans, many of them even sleeping in the same bed as their owners [19]. It is also common for pet cats to have access to outdoor areas where there is a high likelihood of exposure to ectoparasites or pathogens. Given the high frequency of very close contact between cats and their owners, as well as between cats and other domestic animals, cats can play an important role in the maintenance and transmission of zoonotic agents to humans. The transmission of the causative agent of CSD from felines to humans has been reported all over the world [20-23]. 
There is limited information about CSD and other Bartonella infections in humans in Lithuania. The oldest known cases of a lice-borne disease caused by B. quintana were reported in soldiers in Napoleon's Grande Armée in Vilnius [24]. Specific antibodies to $B$. henselae in human serum samples were detected by serologic testing in 2006 in Lithuania's National Public Health Surveillance Laboratory [25]. To date, two cases of CSD in Lithuania have been described in the literature, in 2008 and 2014, respectively. The first case of CSD-associated encephalopathy in a 16-year-old boy was confirmed based on clinical manifestations and positive serology in 2007 [26]. The other known clinical case of cat-scratch neuroretinitis (ocular bartonellosis) was reported in 2014 in a patient in a Lithuanian hospital [27].

One of the most important methods of zoonosis prevention is an investigation of the prevalence of pathogens in their vectors and reservoir hosts $[3,28,29]$. However, there is still a lack of studies on vector-borne zoonotic pathogens from cats and their ectoparasites. In view of the emergence of zoonotic Bartonella infections, plus the ubiquity and abundance of cats and their close association with humans and the absence of information about occurrences of Bartonella spp. in the Lithuanian population of domestic cats and their ectoparasites, the aim of this study was to investigate the presence of Bartonella in pet and stray cats and cat fleas and to characterize Bartonella strains by PCR and sequence analysis of the 16S-23S rRNA intergenic species region (ITS).

\section{Results}

Blood samples were collected from 163 cats, 90 (55.2\%) of which were male and 73 female (44.8\%). The age of the cats ranged from three months to nineteen years (with a median of four years). Cats were divided into two age groups: young kittens $<1$ year old $(\mathrm{n}=20)$ and adults $>1$ year old $(\mathrm{n}=143)$. Based on their health status, cats were divided into apparently healthy $(57.7 \% ; n=94)$ and sick $(42.3 \% ; n=69)$.

A total of 102 fleas representing two species, Ct. felis $(\mathrm{n}=92)$ and Ctenocephalides canis $(\mathrm{n}=10)$, were collected from twelve owned domestic cats. Flea infestation ranged from one to thirty-four fleas per cat. The fleas were $27.5 \%(\mathrm{n}=28)$ male and $72.5 \%(\mathrm{n}=74)$ female.

Bartonella DNA was detected in 4.9\% (8/163) of cat samples and $29.4 \%(30 / 102)$ of flea samples (Table 1). Among the PCR-positive cats, three (37.5\%) were young kittens, and five $(62.5 \%)$ were adults. Bartonella spp. DNA was detected in $27.8 \%(5 / 18)$ of the stray cats and $2.1 \%(3 / 145)$ of the pet cats $\left(\chi^{2}=22.68, p<0.05\right)$. Clinical signs of Bartonella infection were observed in 50\% $(\mathrm{n}=4)$ of the infected cats: $12.5 \%$ of the animals had lethargy, $12.5 \%$ diarrhea, $12.5 \%$ visual impairment, and $12.5 \%$ altered general blood test parameters (Table 2).

Table 1. Bartonella spp. in cats and cat fleas confirmed based on PCR and sequencing.

\begin{tabular}{|c|c|c|c|c|c|c|}
\hline Cats/Fleas & & $n^{1}$ & B. henselae & B. clarridgeiae & B. schoenbuchensis-Like & Total \\
\hline \multirow{2}{*}{ Stray cats } & $<1$-year-old & 9 & 1 & 0 & 1 & 2 \\
\hline & >1-year-old & 9 & 2 & 1 & 0 & 3 \\
\hline \multirow{2}{*}{ Pet cats } & $<1$-year-old & 11 & 1 & 0 & 0 & 1 \\
\hline & $>1$-year-old & 134 & 0 & 1 & 1 & 2 \\
\hline \multicolumn{2}{|c|}{ Total } & 163 & 4 & 2 & 2 & 8 \\
\hline \multirow{2}{*}{ Ct. felis } & male & 24 & 2 & 0 & 1 & 3 \\
\hline & female & 68 & 15 & 3 & 4 & 22 \\
\hline \multirow[b]{2}{*}{ Ct. canis } & male & 4 & 0 & 0 & 2 & 2 \\
\hline & female & 6 & 2 & 0 & 1 & 3 \\
\hline \multicolumn{2}{|c|}{ Total } & 102 & 19 & 3 & 8 & 30 \\
\hline
\end{tabular}


Table 2. Characteristics of Bartonella infection in cats.

\begin{tabular}{|c|c|c|c|c|c|}
\hline & \multicolumn{2}{|c|}{ Age } & \multirow{3}{*}{$\begin{array}{c}\text { Sex } \\
q \\
q\end{array}$} & \multirow{3}{*}{$\begin{array}{c}\text { Clinical Symptoms } \\
\text { No symptoms } \\
\text { Corneal ulcer }\end{array}$} & \multirow{3}{*}{$\begin{array}{c}\text { Bartonella spp. } \\
\text { B. schoenbuchensis-like } \\
\text { B. henselae }\end{array}$} \\
\hline \multirow{5}{*}{ Stray cats } & & 5 months & & & \\
\hline & <1-year-old & 6 months & & & \\
\hline & & 6 years & 우 & No symptoms & B. henselae \\
\hline & >1-year-old & 3 years & $\sigma^{2}$ & No symptoms & B. henselae \\
\hline & & 4 years & $\sigma^{7}$ & Diarrhea & B. clarridgeiae \\
\hline \multirow{3}{*}{ Pet cats } & $<1$-year-old & 8 months & q & Lethargy & B. henselae \\
\hline & $>1$-year-old & 10 years & q & $\begin{array}{c}\text { RBC and haemoglobin } \\
\text { levels low }\end{array}$ & B. schoenbuchensis-like \\
\hline & & 8 years & $0^{7}$ & no symptoms & B. clarridgeiae \\
\hline
\end{tabular}

ф-female; $0^{7}-$ male.

Bartonella-positive fleas were obtained from six owned cats (one young kitten and five adults). The percentage of fleas infected with Bartonella spp. varied among cat hosts from 6.3 to $50 \%$ (Table 3). Both flea species harbored Bartonella pathogens. Of the thirty Bartonella-positive fleas, 25 (83.3\%) were Ct. felis and five (16.7\%) were Ct. canis $\left(\chi^{2}=2.26\right.$, $p>0.05)$. Bartonella DNA was detected in $17.9 \%(5 / 28)$ of male fleas and $33.8 \%(25 / 74)$ of female fleas $\left(\chi^{2}=2.48, p>0.05\right)$ (Table 1$)$.

Table 3. Detection of Bartonella in cat fleas.

\begin{tabular}{ccccc}
\hline Cats & No of Bartonella Positive/No of Tested Fleas (\%) & B. henselae & B. clarridgeiae & B. schoenbuchensis-Like \\
\hline 1 & $17 / 34(50 \%)$ & 11 & 2 & 4 \\
2 & $1 / 16(6.3 \%)$ & 1 & 0 & 0 \\
3 & $6 / 14(42.9 \%)$ & 3 & 0 & 3 \\
4 & $3 / 12(25 \%)$ & 1 & 0 & 1 \\
5 & $2 / 5(40 \%)$ & 1 & 1 & 0 \\
6 & $1 / 3(33.3 \%)$ & 0 & 0 \\
\hline
\end{tabular}

A total of 38 Bartonella 16S-23S rRNA ITS region sequences (eight from cats and 30 from fleas) were analyzed. Sequence analysis demonstrated that the cats and fleas were infected with B. henselae (23 sequences; MZ061902-MZ061911), B. clarridgeiae (five sequences; MZ061900-MZ061901) and Bartonella sp., closely related to B. schoenbuchensis (ten sequences; MZ061922-MZ061927) (Table 1; Figure 1). The phylogenetic tree showed three well-supported clusters (Figure 1). One cluster contained the human- and cat-associated species B. henselae, B. koehlerae and B. quintana. Another cluster consisted of ruminantassociated Bartonella spp. (B. schoenbuchensis and B. bovis). The third group included different $B$. clarridgeiae strains. The ITS sequences of $B$. henselae, B. clarridgeiae and Bartonella $\mathrm{sp}$. derived from cats and fleas in this study were heterogenic. Among the Lithuanian $B$. henselae isolates, three ITS genotypes (two in cats and two in fleas) with five variable nucleotides were detected (Table 4). Two cat specimens and three Ct. felis flea specimens harbored two different $B$. clarridgeiae genotypes, respectively (differing at two nucleotide positions). The $B$. henselae and $B$. clarridgeiae ITS region sequences obtained in this study were $98-100 \%$ identical to the corresponding sequences available in GenBank. Twenty $B$. henselae ITS sequences obtained in the cats and fleas were 100\% identical to the URBHLIE 9 strain (which had previously been isolated from patients with endocarditis) and differed from the Houston-1 strain (identified in both animals and humans and involved in CSD) by one nucleotide substitution $(C \rightarrow G)$ at position 66 in the analyzed sequences [30]. Two other $B$. henselae ITS sequences obtained in this study were specific to Lithuanian samples and were closely related to CAL-1 and URBHLLY 8 strains (differing by one and four nucleotides, respectively) previously isolated from human patients in France (Table 4; Figure 1). 


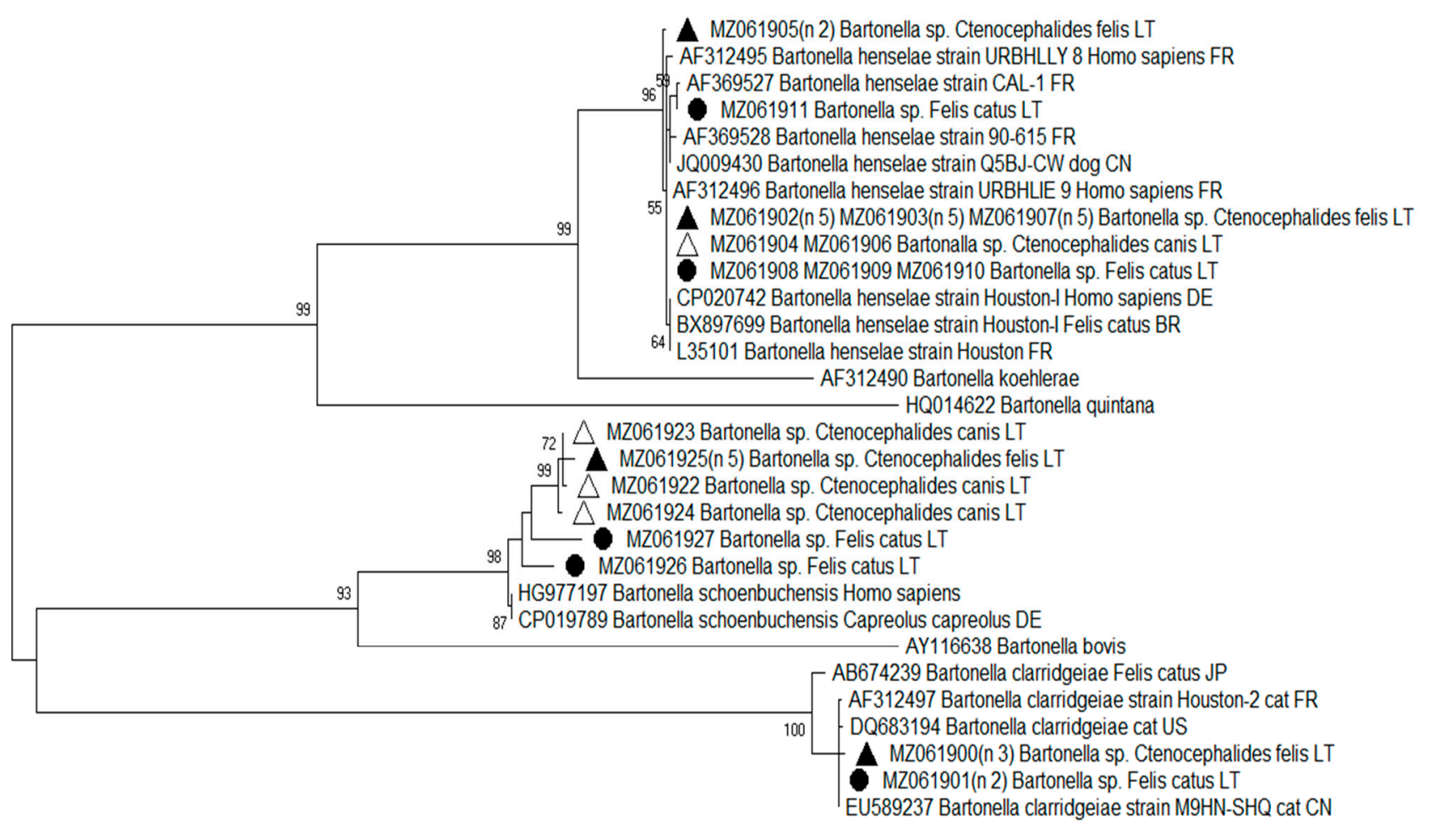

0.050

Figure 1. Phylogenetic tree for the partial ITS region of Bartonella spp. inferred using the maximum-likelihood method and Tamura 3-parameter model with 1000 bootstrapping replications. Samples sequenced in the present study are marked with - (Felis catus), $\mathbf{\Delta}$ (Ctenocephalides felis) and $\Delta$ (Ctenocephalides canis). The number of samples represented by the sequence is given in parentheses $(\mathrm{n} x)$.

Table 4. Differences in the 16S-23S rRNA ITS nucleotide sequences among Bartonella henselae strains from Lithuania and other countries. Sequences detected in this study are in bold. The number of samples represented by the sequence is given in parentheses $(n=x)$.

\begin{tabular}{|c|c|c|c|c|c|c|c|c|c|c|c|c|}
\hline \multirow{2}{*}{ GenBank Accession Numbers } & \multicolumn{10}{|c|}{ Nucleotide Positions } & \multirow{2}{*}{ Strain } & \multirow{2}{*}{$\begin{array}{c}\text { Geographic } \\
\text { Origin }\end{array}$} \\
\hline & 66 & 276 & 343 & 429 & 496 & 628 & 652 & 707 & 744 & 776 & & \\
\hline CP020742; BX897699; L35101 & $\mathrm{C}$ & A & $\mathrm{C}$ & $\mathrm{T}$ & $\mathrm{C}$ & A & $\mathrm{T}$ & G & $\mathrm{T}$ & $\mathrm{T}$ & Houston & $\begin{array}{c}\text { Germany, } \\
\text { Brazil, France }\end{array}$ \\
\hline $\begin{array}{l}\text { AF312496; MZ061902 (n = 5), } \\
\text { MZ061903 (n = 5 ), MZ061904, } \\
\text { MZ061906, MZ061907 (n= 5), } \\
\text { MZ061908, MZ061909, } \\
\text { MZ061910 }\end{array}$ & G & A & $\mathrm{C}$ & $\mathrm{T}$ & $\mathrm{C}$ & A & $\mathrm{T}$ & G & $\mathrm{T}$ & $\mathrm{T}$ & URBHLIE 9 & $\begin{array}{l}\text { France, } \\
\text { Lithuania }\end{array}$ \\
\hline $\operatorname{MZ061905~}(\mathrm{n}=2)$ & G & A & $\mathrm{T}$ & $\mathrm{C}$ & $\mathrm{C}$ & $\mathrm{A}$ & $\mathrm{T}$ & G & $\mathrm{T}$ & $\mathrm{T}$ & & Lithuania \\
\hline MZ061911 & G & A & $\mathrm{C}$ & $\mathrm{T}$ & $\mathrm{T}$ & G & $\mathrm{T}$ & $\mathrm{A}$ & $\mathrm{T}$ & $\mathrm{T}$ & & Lithuania \\
\hline AF369527 & G & A & $\mathrm{C}$ & $\mathrm{T}$ & $\mathrm{T}$ & G & A & A & $\mathrm{T}$ & $\mathrm{T}$ & CAL-1 & France \\
\hline JQ009430 & G & $\mathrm{A}$ & $\mathrm{C}$ & $\mathrm{T}$ & $\mathrm{C}$ & $\mathrm{G}$ & $\mathrm{T}$ & G & $\mathrm{T}$ & $\mathrm{T}$ & Q5BJ-CW & China \\
\hline AF369528 & G & $\mathrm{C}$ & $\mathrm{C}$ & $\mathrm{T}$ & $\mathrm{C}$ & G & A & G & $\mathrm{T}$ & $\mathrm{T}$ & $90-615$ & France \\
\hline AF312495 & G & A & $\mathrm{C}$ & $\mathrm{T}$ & $\mathrm{C}$ & $\mathrm{A}$ & $\mathrm{T}$ & G & $\mathrm{C}$ & $\mathrm{C}$ & URBHLLY 8 & France \\
\hline
\end{tabular}

Genetic heterogeneity was found to be higher among Bartonella sequences more closely related to B. schoenbuchensis, with DNA similarity values from 95 to $96 \%$ and six genotypes identified. Bartonella isolates derived from cats and from Ct. canis and Ct. felis fleas were species-specific and differing by thirty-two nucleotide positions. Bartonella sequences (MZ061926 and MZ061927) obtained in two cats were 96-98\% identical (differing at eight 
and sixteen nucleotides, respectively) to the corresponding sequence of the B. schoenbuchensis strain detected in humans (HG977197). Ctenocephalides canis and Ct. felis fleas harbored Bartonella genotypes (MZ061922-MZ061925), which shared 94-98\% similarity in the ITS region sequence (differing from ten to fourteen nucleotide positions) with $B$. schoenbuchensis isolates derived from human and roe deer (HG977197 and CP019789) (Figure 1).

\section{Discussion}

This study is the first report of the presence of Bartonella infections in cats and cat fleas in Lithuania. Two causative agents of cat-scratch disease, B. henselae and B. clarridgeiae, were identified in the cats and fleas, and $B$. henselae was found to be more common than B. clarridgeiae.

In Europe, serological prevalence rates of Bartonella infections in cats are high in European Mediterranean countries, where the temperature and humidity are favorable for flea infestation, and range from $0 \%$ in Norway to $71.4 \%$ in Spain. PCR-confirmed cases of feline bartonellosis have rarely been reported, with the molecular prevalence of Bartonella infection in cats ranging from $0 \%$ in north-east Germany to $83.5 \%$ in Italy [3].

Bartonella species appear to be highly adapted to one or a few mammalian reservoir hosts. Infection in these hosts is characterized by long-lasting intraerythrocytic bacteraemia $[6,31]$. The clinical spectrum of the infection in felines has not been fully investigated, but naturally infected animals seem to be healthy carriers. In cases when symptoms appear, they are most commonly mild clinical signs. Experimentally infected cats have shown signs of lymphadenopathy, myalgia and transient fever with lethargy and anorexia during febrile periods [1]. Young and stray cats are more likely to be carriers of the pathogen than older $(>1$ year) or pet cats $[1,32,33]$. The results of the present study showed that $50 \%$ of the infected cats had certain medical conditions, which can be associated with Bartonella infection (lethargy, diarrhea, visual impairment, and altered general blood test parameters).

The prevalence of Bartonella infection was significantly higher in the stray cats than in the pet cats $\left(27.8\right.$ and $2.1 \%$, respectively; $\left.\chi^{2}=22.68, p<0.05\right)$, and cats in the adult age group were more frequently infected than young kittens ( 62.5 and $37.5 \%$, respectively; $\chi^{2}=4.98$, $p<0.05)$. Among the 90 male and 73 female cats tested, three (3.3\%) and five $(6.9 \%)$ specimens, respectively were infected. However, the detected difference in the prevalence of infection between males and females was not statistically significant $\left(\chi^{2}=1.07, p>0.05\right)$. Although previous studies have demonstrated that male and younger cats are more likely to be infected with Bartonella pathogens due to their potentially more aggressive nature $[34,35]$, such data were not obtained in the present study.

The pathogens can be transmitted among cats or from cats to humans by scratches or bites by infected animals or cat fleas, and through the feces of infected fleas [31,36]. In Europe, due to their widespread distribution, fleas are especially important in the transmission of Bartonella species from pets to humans. Ctenocephalides felis is the most common flea species found on cats, followed by $C t$. canis $[18,37]$. In the present study, two flea species-cat flea $\mathrm{Ct}$. felis and dog flea $\mathrm{Ct}$. canis-were collected from owned (outdoor/indoor) domestic cats living in suburban and rural areas. Ctenocephalides felis was more abundant $(90.92 \%$ of the total; collected from twelve cats) than $C t$. canis ( $9.8 \%$ of the total; only found on three cats). Bartonella spp. were detected in 27.2\% (25/92) of the Ct. felis and $50 \%(5 / 10)$ of the $C t$. canis fleas. Sequence analysis of positive samples showed that both species of fleas harbored B. henselae, while B. clarridgeiae was only detected in $C t$. felis. These results confirmed that $C t$. felis and $C t$. canis fleas may play an important role in the transmission of zoonotic Bartonella species in Lithuania. Bartonella henselae and B. clarridgeiae in cat fleas have also been reported in other studies conducted worldwide [2,12-18,38].

Unexpectedly in this study, Bartonella genotypes closely related genetically to $B$. schoenbuchensis were detected in cats and in both flea species. These Bartonella genotypes have not yet been documented as infecting cats in Europe. Bartonella schoenbuchensis strains are associated with ruminants and usually transmitted by deer keds (Lipoptena spp.) [39-42]. In Lithuania, strains closely related to B. schoenbuchensis have been detected in deer keds 
Lipoptena cervi and Lipoptena fortisetosa (GenBank: MT873590-MT873595) [43]. Wild and domestic ruminants have also been found to harbor Bartonella capreoli, Bartonella chomelii, Bartonella melophagi and Bartonella bovis [40,44,45]. Bartonella schoenbuchensis, B. capreoli and $B$. chomelii (which have been isolated from roe deer, red deer and cattle) are genetically and biologically close species and are members of the same Bartonella clade [46]. Bartonella bovis (formerly Bartonella weissii) is commonly detected in cattle [44,47-49] and can cause endocarditis in infected animals [50]. However, this species was originally isolated from four domestic cats from Utah and Illinois (USA) and, together with B. henselae, B. clarridgeiae, and $B$. koehlerae, was reported as the fourth Bartonella species found to infect cats in North America [1,51]. Breitschwerdt et al. suggested that the detection of B. weissii in both cats and cattle may reflect an unusual evolutionary adaptation for this particular Bartonella species [47].

Due to their high interspecies variability and low intraspecies variability, several protein-encoding genes, such as those encoding cell division protein (ftsZ), citrate-synthase (gltA), haem-binding protein (pap31), heat-shock protein (groEL), NADH dehydrogenase gamma subunit (nuoG), riboflavin synthase (ribC), RNA polymerase beta-subunit (rpoB), 17-kDa antigen, 35-kDa protein and the 16S rRNA gene, have been used to infer evolutionary relationships between Bartonella strains and identify genotypes [2,52-56]. 16S-23S rRNA ITS sequences have also been confirmed as a useful tool for phylogenetic analyses at the interspecies level and for Bartonella species subtyping [30]. Molecular characterization of $B$. henselae strains demonstrates the genotypic heterogeneity of $B$. henselae in patients with CSD. Based on 16S rRNA sequence analysis, two main genotypes of $B$. henselae in human patients with cat-scratch disease have been described and correspond to two serotypes: Houston-1 and Marseille [17,56,57].

The present study demonstrated genetic heterogeneity among B. henselae and B. clarridgeiae strains circulating in cats and fleas in Lithuania. The B. clarridgeiae sequences obtained showed $99-100 \%$ identity to B. clarridgeiae detected in cats in France, China, Japan and the USA (AF312497, EU589237, AB674239 and DQ683194). The B. henselae ITS sequences showed high identity (99-100\%) with $B$. henselae strains isolated from patients infected with CSD in France (AF312496) and with the B. henselae Houston-I genotype detected in cats and humans in Germany, France and Brazil (CP020742, BX897699 and L35101). The $B$. henselae Marseille genotype is known to be dominant in cat populations in western Europe, the western United States and Australia, while the Houston genotype is dominant in Asia $[58,59]$. However, the prevalence of different $B$. henselae genotypes may vary among cat populations in the same country. In France, the Marseille genotype has been shown to be dominant in central France, while the Houston genotype is dominant in the south of France [32]. There is evidence that these two genotypes vary in their zoonotic potential: Houston has been associated with more severe clinical manifestations than those induced by Marseille [60].

It has been suggested that Bartonella infections may persist in both cats and fleas. Although most cats infected with B. henselae and B. clarridgeiae are usually asymptomatic, they serve as reservoirs of these bacteria and transmit the infection to humans. As reservoir hosts for B. henselae, cats can be subclinically infected for months and even years [3]. The present findings suggest a potential risk of humans acquiring CSD causative agents in Lithuania and underline the need for the routine diagnosis of Bartonella infections in Lithuania's cat population.

\section{Materials and Methods}

\subsection{Sample Collection}

Blood samples were taken from 163 domestic cats in two veterinary clinics $(n=145)$ and two animal shelters $(n=18)$ in Kaunas (Central Lithuania) in 2016-2018. Feline blood samples were taken from the cephalic vein into tubes containing EDTA and kept at +4 or $-20{ }^{\circ} \mathrm{C}$ until DNA isolation. The clinical symptoms, sex and age of the cats were recorded 
during a physical examination. Information about outdoor access or the flea infestation status of cats collected in veterinary clinics and animal shelters was not available.

Fleas were collected from 12 owned domestic cats that live both outdoors and indoors in two Lithuanian districts (Kaunas and Joniškis) in 2015-2016. The fleas collected from each cat were placed in separate $1.5 \mathrm{~mL}$ tubes with $70 \%$ ethanol, and kept at $+4{ }^{\circ} \mathrm{C}$ until investigation. Flea species were identified by morphological criteria [37].

\subsection{DNA Extraction and PCR Amplification}

DNA from the blood of the cats was extracted using a GeneJet Whole Blood Genomic DNA Purification Kit (Thermo Fisher Scientific, Lithuania), according to the manufacturer's instructions. DNA from fleas was extracted from each specimen individually using $2.5 \%$ ammonium hydroxide solution [61].

Nested PCR targeting the 16S-23S rRNA ITS region was performed using the external primers WITS-F (5-ACC TCC TTT CTA AGG ATG AT-3') and WITS-R (5-CTC TTT CTT CAG ATG ATG ATCC- $\left.3^{\prime}\right)$ and internal primers Bh311-332F (5'-CTC TTT CTT CAG ATG ATG ATCC-3') and ITS-R (ITS)(5-GCG GTT AAG CTT CCA ATC ATA-3'), according to previously described protocols [62,63]. Negative controls consisting of sterile, doubledistilled water added to the first PCR mix rather than DNA were included after every five experimental samples.

PCR products were visualized on a 1.5\% agarose gel (Thermo Fisher Scientific, Vilnius, Lithuania). Bartonella-positive samples selected for DNA sequencing were purified using the GeneJET ${ }^{\mathrm{TM}}$ Gel Extraction Kit (Thermo Fisher Scientific, Vilnius, Lithuania) and sequenced (Macrogen Europe company, Amsterdam, The Netherlands).

The obtained sequences were edited and then aligned with each other and with Bartonella spp. 16S-23S rRNA ITS region sequences were registered in the GenBank database by using BLAST and MUSCLE computer algorithms implemented in the Mega X software package [64]. A phylogenetic tree was constructed using the maximum-likelihood (ML) method with the Tamura 3-parameter model and bootstrap analysis of 1000 replicates.

Partial 16S-23S rRNA ITS region sequences for representative samples obtained in this study were submitted to the GenBank database under the accession numbers MZ061900MZ061911 and MZ061922-MZ061927.

\subsection{Statistical Analysis}

A Chi-square test (Statistica for Windows, version 7.0, Statsoft, Tulsa, OK, USA) was used to compare the prevalence of Bartonella in cats and cat fleas. The observed differences were considered to be significant when $p<0.05$.

Author Contributions: Conceptualization, A.P. and J.R.; methodology, M.R., I.L. and J.R.; software, M.R., I.L. and J.R.; formal analysis, M.R. and I.L.; investigation, M.R. and I.L.; resources, B.K., V.R., M.R. and I.L.; writing—original draft preparation, M.R. and I.L.; writing—review and editing, A.P., B.K., V.R. and J.R. All authors have read and agreed to the published version of the manuscript.

Funding: This research received no external funding.

Institutional Review Board Statement: Ethical review and approval were waived for this study, as cats were sampled in the framework of their routine medical checks coordinated by local veterinarians. All clinical procedures with the animals followed in this study were in accordance with Lithuanian (Republic of Lithuania Law on Welfare and Protection of Animals No. XI-2271) and European legislation for the protection of animals and met the International Guiding Principles for Biomedical Research Involving Animals. Informed consent and agreement were obtained from cat owners before sampling fleas.

Informed Consent Statement: Not applicable.

Data Availability Statement: Data are contained within the article.

Conflicts of Interest: The authors declare no conflict of interest. 


\section{References}

1. Chomel, B.B.; Boulouis, H.J.; Breitschwerdt, E.B. Cat scratch disease and other zoonotic Bartonella infections. J. Am. Vet. Med. Assoc. 2004, 224, 1270-1279. [CrossRef] [PubMed]

2. Bai, Y.; Rizzo, M.F.; Alvarez, D.; Moran, D.; Peruski, L.F.; Kosoy, M. Coexistence of Bartonella henselae and B. clarridgeiae in populations of cats and their fleas in Guatemala. J. Vector. Ecol. 2015, 40,327-332. [CrossRef]

3. Álvarez-Fernández, A.; Breitschwerdt, E.B.; Solano-Gallego, L. Bartonella infections in cats and dogs including zoonotic aspects. Parasit. Vectors 2018, 11, 624. [CrossRef] [PubMed]

4. Cheslock, M.A.; Embers, M.E. Human bartonellosis: An underappreciated public health problem? Trop. Med. Infect. Dis. 2019, 4, 69. [CrossRef]

5. Hayman, D.T.; McDonald, K.D.; Kosoy, M.Y. Evolutionary history of rat-borne Bartonella: The importance of commensal rats in the dissemination of bacterial infections globally. Ecol. Evol. 2013, 3, 3195-3203. [CrossRef]

6. Breitschwerdt, E.B. Bartonellosis, One Health and all creatures great and small. Vet. Dermatol. 2017, 8, 111-121. [CrossRef]

7. Sandoval, A.C.; Reyes, F.T.; Prado, M.A.; Peña, A.L.; Viviani, T.N. Cat-scratch disease in the pediatric population: 6 years of evaluation and follow-up in a public hospital in Chile. Pediatr. Infect. Dis. J. 2020, 39, 889-893. [CrossRef]

8. Hjelm, E.; McGill, S.; Blomqvist, G. Prevalence of antibodies to Bartonella henselae, B. elizabethae and B. quintana in Swedish domestic cats. Scand. J. Infect. Dis. 2002, 34, 192-196. [CrossRef]

9. La, V.D.; Tran-Hung, L.; Aboudharam, G.; Raoult, D.; Drancourt, M. Bartonella quintana in domestic cat. Emerg. Infect. Dis. 2005, 11, 1287-1289. [CrossRef]

10. Varanat, M.; Travis, A.; Lee, W.; Maggi, R.G.; Bissett, S.A.; Linder, K.E.; Breitschwerdt, E.B. Recurrent osteomyelitis in a cat due to infection with Bartonella vinsonii subsp. berkhoffii genotype II. J. Vet. Intern. Med. 2009, 23, 1273-1277. [CrossRef]

11. Chomel, B.B.; Kasten, R.W.; Floyd-Hawkins, K.; Chi, B.; Yamamoto, K.; Roberts-Wilson, J.; Gurfield, A.N.; Abbott, R.C.; Pedersen, N.C.; Koehler, J.E. Experimental transmission of Bartonella henselae by the cat flea. J. Clin. Microbiol. 1996, 34, 1952-1956. [CrossRef]

12. Tsai, Y.L.; Lin, C.C.; Chomel, B.B.; Chuang, S.T.; Tsai, K.H.; Wu, W.J.; Huang, C.G.; Yu, J.C.; Sung, M.H.; Kass, P.H.; et al. Bartonella infection in shelter cats and dogs and their ectoparasites. Vector Borne Zoonotic Dis. 2011, 11, 1023-1030. [CrossRef]

13. Gutiérrez, R.; Nachum-Biala, Y.; Harrus, S. Relationship between the presence of Bartonella species and bacterial loads in cats and cat fleas (Ctenocephalides felis) under natural conditions. Appl. Environ. Microbiol. 2015, 81, 5613-5621. [CrossRef]

14. Rolain, J.M.; Franc, M.; Davoust, B.; Raoult, D. Molecular detection of Bartonella quintana, B. koehlerae, B. henselae, B. clarridgeiae, Rickettsia felis, and Wolbachia pipientis in cat fleas, France. Emerg. Infect. Dis. 2003, 9, 338-342. [CrossRef]

15. Rizzo, M.F.; Billeter, S.A.; Osikowicz, L.; Luna-Caipo, D.V.; Cáceres, A.G.; Kosoy, M. Fleas and flea-associated Bartonella species in dogs and cats from Peru. J. Med. Entomol. 2015, 52, 1374-1377. [CrossRef]

16. Zouari, S.; Khrouf, F.; M'ghirbi, Y.; Bouattour, A. First molecular detection and characterization of zoonotic Bartonella species in fleas infesting domestic animals in Tunisia. Parasit. Vectors 2017, 10, 436. [CrossRef]

17. Müller, A.; Rodríguez, E.; Walker, R.; Bittencourt, P.; Pérez-Macchi, S.; Gonçalves, L.R.; Machado, R.Z.; André, M.R. Occurrence and genetic diversity of Bartonella spp. (Rhizobiales: Bartonellaceae) and Rickettsia spp. (Rickettsiales: Rickettsiaceae) in cat fleas (Siphonaptera: Pulicidae) from Chile. J. Med. Entomol. 2018, 55, 1627-1632. [CrossRef]

18. Abdullah, S.; Helps, C.; Tasker, S.; Newbury, H.; Wall, R. Pathogens in fleas collected from cats and dogs: Distribution and prevalence in the UK. Parasit. Vectors 2019, 12, 71. [CrossRef]

19. Chomel, B.B.; Sun, B. Zoonoses in the bedroom. Emerg. Infect. Dis. 2011, 17, 167-172. [CrossRef]

20. Gilbert, G.L.; Flexman, J.P.; Pearman, J.W.; Chen, S.C.; Dickeson, D.J.; Gilbert, G.L. Detection of antibodies to Bartonella henselae in clinically diagnosed cat scratch disease. Med. J. Aust. 1997, 166, 532-535. [CrossRef]

21. Massei, F.; Gori, L.; Macchia, P.; Maggiore, G. The expanded spectrum of bartonellosis in children. Infect. Dis. Clin. N. Am. 2005, 19, 691-711. [CrossRef]

22. Klotz, S.A.; Ianas, V.; Elliott, S.P. Cat-scratch disease. Am. Fam. Physician. 2011, 83, 152-155. [PubMed]

23. Türker, K.; Çelebi, B.; Andaç, Ş.; Bulut, P.; Yalçın, Ş.; Dolhan, S. A negleted bacteria with a case: Bartonella henselae. Mikrobiyol. Bul. 2017, 51, 286-292. [CrossRef] [PubMed]

24. Raoult, D.; Dutour, O.; Houhamdi, L.; Jankauskas, R.; Fournier, P.E.; Ardagna, Y.; Drancourt, M.; Signoli, M.; La, V.D.; Macia, Y.; et al. Evidence for louse-transmitted diseases in soldiers of Napoleon's Grand Army in Vilnius. J. Infect. Dis. 2006, 193, 112-120. [CrossRef] [PubMed]

25. Zygutiene, M.; Virbaliene, R.; Ziliukiene, J.; Jasulaitiene, V. Research on cat scratch disease in Lithuania. Lith. Gen. Practitioner. 2006, 10, 565-567. (In Lithuanian)

26. Grikiniene, J.; Sidlovskaite, D. Cat-Scratch disease with encephalopathy. Semin. Neurosci. 2008, 12, 42e5. (In Lithuanian)

27. Kovaliunas, E.; Sirtautiene, R.; Cimbalas, A. Cat-scratch disease. Clinical case. Lith. Ophthalmol. 2014, 13, 33-35. (In Lithuanian)

28. Frank, H.K.; Boyd, S.D.; Hadly, E.A. Global fingerprint of humans on the distribution of Bartonella bacteria in mammals. PLoS Negl. Trop. Dis. 2018, 12, e0006865. [CrossRef]

29. Donovan, T.A.; Balakrishnan, N.; Barbosa, I.C.; McCoy, T.; Breitschwerdt, E.B.; Fox, P.R. Bartonella spp. as a possible cause or cofactor of feline endomyocarditis-left ventricular endocardial fibrosis complex. J. Comp. Pathol. 2018, 162, 29-42. [CrossRef]

30. Houpikian, P.; Raoult, D. 16S/23S rRNA intergenic spacer regions for phylogenetic analysis, identification, and subtyping of Bartonella species. J. Clin. Microbiol. 2001, 39, 2768-2778. [CrossRef] 
31. Chomel, B.B.; Boulouis, H.J.; Maruyama, S.; Breitschwerdt, E.B. Bartonella spp. in pets and effect on human health. Emerg. Infect. Dis. 2006, 12, 389-394. [CrossRef]

32. Boulouis, H.J.; Chang, C.C.; Henn, J.B.; Kasten, R.W.; Chomel, B.B. Factors associated with the rapid emergence of zoonotic Bartonella infections. Vet. Res. 2005, 36, 383-410. [CrossRef]

33. Bergmann, M.; Englert, T.; Stuetzer, B.; Hawley, J.R.; Lappin, M.R.; Hartmann, K. Prevalence of Bartonella species infections in cats in Southern Germany. Vet. Rec. 2017, 180, 325. [CrossRef] [PubMed]

34. Ueno, H.; Muramatsu, Y.; Chomel, B.B.; Hohdatsu, T.; Koyama, H.; Morita, C. Seroepidemiological survey of Bartonella (Rochalimaea) henselae in domestic cats in Japan. Microbiol. Immunol. 1995, 39, 339-341. [CrossRef]

35. Maruyama, S.; Hiraga, S.; Yokoyama, E.; Naoi, M.; Tsuruoka, Y.; Ogura, Y.; Tamura, K.; Namba, S.; Kameyama, Y.; Nakamura, S.; et al. Seroprevalence of Bartonella henselae and Toxoplasma gondii infections among pet cats in Kanagawa and Saitama Prefectures. J. Vet. Med. Sci. 1998, 60, 997-1000. [CrossRef]

36. Bradbury, C.A.; Lappin, M.R. Evaluation of topical application of 10\% imidacloprid-1\% moxidectin to prevent Bartonella henselae transmission from cat fleas. J. Am. Vet. Med. Assoc. 2010, 236, 869-873. [CrossRef]

37. Rosicky, B. Fauna ČSR Blechy-Aphaniptera; ČSAV: Praha, Czech Republic, 1957. (In Czech)

38. Tsai, K.H.; Huang, C.G.; Fang, C.T.; Shu, P.Y.; Huang, J.H.; Wu, W.J. Prevalence of Rickettsia felis and the first identification of Bartonella henselae Fizz/CAL-1 in cat fleas (Siphonaptera: Pulicidae) from Taiwan. J. Med. Entomol. 2011, 48, 445-452. [CrossRef] [PubMed]

39. Dehio, C.; Sauder, U.; Hiestand, R. Isolation of Bartonella schoenbuchensis from Lipoptena cervi, a blood-sucking arthropod causing deer ked dermatitis. J. Clin. Microbiol. 2004, 42, 5320-5323. [CrossRef]

40. Halos, L.; Jamal, T.; Maillard, R.; Girard, B.; Guillot, J.; Chomel, B.; Vayssier-Taussat, M.; Boulouis, H.J. Role of Hippoboscidae flies as potential vectors of Bartonella spp. infecting wild and domestic ruminants. Appl. Environ. Microbiol. 2004, 70, $6302-6305$. [CrossRef]

41. Reeves, W.K.; Nelder, M.P.; Cobb, K.D.; Dasch, G.A. Bartonella spp. in deer keds, Lipoptena mazamae (Diptera: Hippoboscidae), from Georgia and South Carolina, USA. J. Wildl Dis. 2006, 42, 391-396. [CrossRef]

42. Razanske, I.; Rosef, O.; Radzijevskaja, J.; Klepeckiene, K.; Lipatova, I.; Paulauskas, A. Infections with Bartonella spp. in free-ranging cervids and deer keds (Lipoptena cervi) in Norway. Comp. Immunol. Microbiol. Infect. Dis. 2018, 58, 26-30. [CrossRef]

43. Paulauskas, A.; Radzijevskaja, J.; Klepeckiene, K.; Razanske, I. Bartonella spp. in Deer Keds and Cervids in Lithuania; Manuscript in Preparation: Kaunas, Lithuania, 2021.

44. Martini, M.; Menandro, M.L.; Mondin, A.; Pasotto, D.; Mazzariol, S.; Lauzi, S.; Stelletta, C. Detection of Bartonella bovis in a cattle herd in Italy. Vet. Rec. 2008, 162, 58-59. [CrossRef]

45. Kosoy, M.; Bai, Y.; Enscore, R.; Rizzo, M.R.; Bender, S.; Popov, V.; Albayrak, L.; Fofanov, Y.; Chomel, B. Bartonella melophagi in blood of domestic sheep (Ovis aries) and sheep keds (Melophagus ovinus) from the southwestern US: Cultures, genetic characterization, and ecological connections. Vet. Microbiol. 2016, 190, 43-49. [CrossRef]

46. Engel, P.; Salzburger, W.; Liesch, M.; Chang, C.C.; Maruyama, S.; Lanz, C.; Calteau, A.; Lajus, A.; Médigue, C.; Schuster, S.C.; et al. Parallel evolution of a type IV secretion system in radiating lineages of the host-restricted bacterial pathogen Bartonella. PLoS Genet. 2011, 7, e1001296. [CrossRef]

47. Breitschwerdt, E.B.; Sontakke, S.; Cannedy, A.; Hancock, S.I.; Bradley, J.M. Infection with Bartonella weissii and detection of Nanobacterium antigens in a North Carolina beef herd. J. Clin. Microbiol. 2001, 39, 879-882. [CrossRef] [PubMed]

48. Bermond, D.; Boulouis, H.J.; Heller, R.; Van Laere, G.; Monteil, H.; Chomel, B.B.; Sander, A.; Dehio, C.; Piémont, Y. Bartonella bovis Bermond et al. sp. nov. and Bartonella capreoli sp. nov., isolated from European ruminants. Int. J. Syst. Evol. Microbiol. 2002, 52, 383-390. [CrossRef]

49. Welc-Falęciak, R.; Grono, K. The first cases of Bartonella bovis infection in cattle from Central Europe. Vet. Microbiol. 2013, 162, 954-956. [CrossRef] [PubMed]

50. Maillard, R.; Petit, E.; Chomel, B.; Lacroux, C.; Schelcher, F.; Vayssier-Taussat, M.; Haddad, N.; Boulouis, H.J. Endocarditis in cattle caused by Bartonella bovis. Emerg. Infect. Dis. 2007, 13, 1383-1385. [CrossRef]

51. Regnery, R.L.; Marano, N.; Jameson, P.; Marston, E.; Jones, D.; Handley, S.; Goldsmith, C.; Greene, C. A fourth Bartonella species, Bartonella weissii, species nova, isolated from domestic cats. In Proceedings of the 15th Meeting of the American Society for Rickettsiology, Captiva Island, FL, USA, 30 April-3 May 2000; p. 16.

52. Ehrenborg, C.; Wesslén, L.; Jakobson, A.; Friman, G.; Holmberg, M. Sequence variation in the ftsZ gene of Bartonella henselae isolates and clinical samples. J. Clin. Microbiol. 2000, 38, 682-687. [CrossRef]

53. Dillon, B.; Valenzuela, J.; Don, R.; Blanckenberg, D.; Wigney, D.I.; Malik, R.; Morris, A.J.; Robson, J.M.; Iredell, J. Limited diversity among human isolates of Bartonella henselae. J. Clin. Microbiol. 2002, 40, 4691-4699. [CrossRef]

54. La Scola, B.; Liang, Z.; Zeaiter, Z.; Houpikian, P.; Grimont, P.A.; Raoult, D. Genotypic characteristics of two serotypes of Bartonella henselae. J. Clin. Microbiol. 2002, 40, 2002-2008. [CrossRef]

55. Zeaiter, Z.; Fournier, P.E.; Raoult, D. Genomic variation of Bartonella henselae strains detected in lymph nodes of patients with cat scratch disease. J. Clin. Microbiol. 2002, 40, 1023-1030. [CrossRef]

56. Li, W.; Chomel, B.B.; Maruyama, S.; Guptil, L.; Sander, A.; Raoult, D.; Fournier, P.E. Multispacer typing to study the genotypic distribution of Bartonella henselae populations. J. Clin. Microbiol. 2006, 44, 2499-2506. [CrossRef] 
57. Duscher, G.G.; Hodžić, A.; Potkonjak, A.; Leschnik, M.W.; Spergser, J. Bartonella henselae and Rickettsia felis detected in cat fleas (Ctenocephalides felis) derived from Eastern Austrian cats. Vector Borne Zoonotic Dis. 2018, 18, 282-284. [CrossRef] [PubMed]

58. Bouchouicha, R.; Durand, B.; Monteil, M.; Chomel, B.B.; Berrich, M.; Arvand, M.; Birtles, R.J.; Breitschwerdt, E.B.; Koelher, J.E.; Maggi, E.; et al. Molecular epidemiology of feline and human Bartonella henselae isolates. Emerg. Infect. Dis. 2009, 15, 813-816. [CrossRef] [PubMed]

59. Mazurek, Ł.; Carbonero, A.; Skrzypczak, M.; Winiarczyk, S.; Adaszek, Ł. Epizootic situation of feline Bartonella infection in eastern Poland. J. Vet. Res. 2020, 64, 79-83. [CrossRef]

60. Woudstra, C.; Fach, P.; Chomel, B.B.; Haddad, N.; Boulouis, H.J. Draft genome sequences of 12 feline Bartonella henselae isolates. Genome Announc. 2017, 5, e00075-17. [CrossRef] [PubMed]

61. Alekseev, A.N.; Dubinina, H.V.; Van De Pol, I.; Schouls, L.M. Identification of Ehrlichia spp. and Borrelia burgdorfery in Ixodes ticks in the Baltic regions of Russia. J. Clin. Microbiol. 2001, 39, 2237-2242. [CrossRef]

62. Jensen, W.A.; Fall, M.Z.; Rooney, J.; Kordick, D.L.; Breitschwerdt, E.B. Rapid identification and differentiation of Bartonella species using a single-step PCR assay. J. Clin. Microbiol. 2000, 38, 1717-1722. [CrossRef]

63. Kaewmongkol, G. Detection and Characterization of Bartonella Species in Western Australia. Ph.D. Thesis, Murdoch Univer-sity, Perth, Australia, 2012.

64. Kumar, S.; Stecher, G.; Li, M.; Knyaz, C.; Tamura, K. MEGA X: Molecular evolutionary genetics analysis across computing platforms. Mol. Biol. Evol. 2018, 35, 1547-1549. [CrossRef] [PubMed] 